will likewise undergo a major improvement through the efforts to generate and detect single-photon sources. The paper by Shields and colleagues is a harbinger of a nascent single-photon technology.
References

1. Knill, E., Laflamme, R. \& Milburn, G. J. Nature 409, 46-52 (2001).

2. Kardynal, B. E., Yuan, Z. L. \& Shields, A. J. Nature Photon. 2 425-428 (2008).

3. Chuang, I. \& Nielsen, M. A. Quantum computation and quantum information (Cambridge Univ. Press, Cambridge, 2000).
4. Nielsen, M. A. Phys. Rev. Lett. 64, 2141 (2004).

5. Browne, D. E. \& Rudolph, T. Phys. Rev. Lett. 95, 010501 (2005).

6. O'Brien, J. L. et al. Phys. Rev. Lett. 93, 080502 (2004).

7. Hennrich, M. et al. New J. Phys. 6, 86 (2004).

8. Miller, A. J., Nam, S. W., Martinis, J. M. \& Sergienko, A. V. Appl. Phys. Lett. 83, 7910793 (2003).

9. Gansen, E. J. et al. Nature Photon. 1, 585-588 (2007).

\title{
DATASTORAGE
}

\section{Blue laser battle}

Gertrude Neumark Rothschild, an emeritus professor from the University of Columbia, is causing a commotion in the optical-data-storage industry by suing more than 30 leading optoelectronics companies for patent infringement over the fabrication and use of blue semiconductor lasers. Several giants in the sector, including Sony and Sanyo, have recently accepted her case and settled, and more look set to follow.

Her claim is that any company using or making blue lasers is infringing two patents she was granted in the early 1990 s. Her patents (US patent numbers 4,904,618 and 5,252,499) outline processes for doping widebandgap semiconductors using primary and secondary dopants to increase the solubility of either dopant in a crystal. It is this process that made the manufacture of short-wavelength LEDs commercially feasible.

When she first filed her complaint with the US International Trade Commission (ITC) in February this year, her action was ridiculed by many industry commentators. No one seemed to believe that one person could take on giants such as Sony, Sanyo, Hitachi, Nokia and LG Electronics. But at the time this article went to press, Neumark Rothschild had already settled with Seoul Semiconductor, Everlight Electronics, Epistar, Sony and Sanyo. Add these successes to earlier settlements with Nichia, Philips Lumileds, Toyoda Gosei and Osram, and it is clear that the industry is finally taking this lone inventor seriously.

Neumark Rothschild filed the patent applications while working at the University of Columbia in the late 1980s. She told Nature Photonics, "My work at Columbia was theoretical and I was working on my own without any agency funding. I developed a method of increasing the amount of conducting dopant in a semiconductor crystal by also incorporating atomic

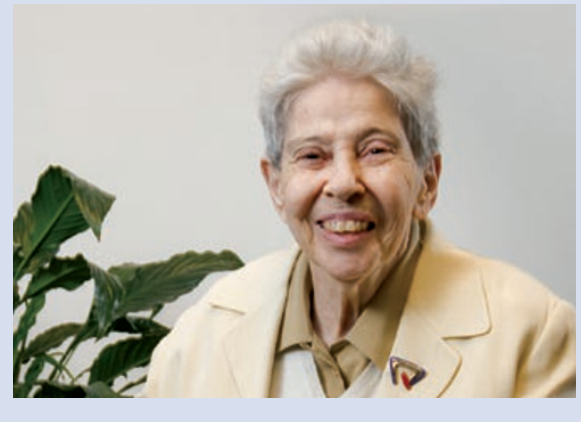

hydrogen and then later removing that atomic hydrogen."

She had previously spent 25 years working at electronics giant Philips, where she learned the value of patenting your work. She felt that patenting her invention was the right way to go and managed to finance the process herself, becoming the sole inventor on her patent. "The timing of my patent application was very lucky," admits Neumark Rothschild. "At around the same time, Japanese researchers verified experimentally what I had proposed theoretically."

Her patents were granted in the early 1990s, around the same time as many large companies were filing, and being granted, patents of their own in the area of blue, or short-wavelength, LEDs. Many even referenced her patents in their patents. But when they started manufacturing blue-laser devices for various applications, including Blu-ray disk players and recorders, none of these companies approached Neumark Rothschild for a licence.

She started defending her patents in the late 1990s when she filed lawsuits against Nichia, Toyoda Gosei, Philips and Osram. "Fortunately early successes in these cases provided seed funding for the ITC case," says Neumark Rothschild. "I chose to file my lawsuit with the ITC rather than go through a federal court case because the process is considerably quicker and more cost-effective."

Neumark Rothschild is described by her university as "a pioneering engineer and one of the world's foremost experts on blue and ultraviolet LEDs". She is the first woman to be given a chair by Columbia's School of Engineering and Applied Sciences and was recently given an honorary Doctor of Science degree by Columbia in recognition of her work as a "trail-blazing female engineer". She has also served as a fellow of the American Physical Society and as a panelist for the National Research Council. But despite her obvious academic and professional achievements, when she filed her complaint with the ITC she was at first not taken seriously by the industry and the press. This may have been because she was a lone inventor and everyone expected her to fail, but she also believes it was because she is female.

Some of the headlines used by bloggers on the Internet included "Old lady sues tech giants for patents", "Senior citizen claims Blu-ray patent infringement" and "Granny emeritus, looking to take down Blu-ray". "If I had been a man, they would never have called me 'Old man' or 'Grandad"' says Neumark Rothschild. "And anyway, I am not looking to 'take down Blu-ray'. I just want recognition for the work that I did, and I want to show that women can do science."

The news is the latest of a string of successful and high-profile lawsuits filed by lone scientists involved in the development of optical data-storage systems. In January 2004, the Japanese researcher Shuji Nakamura won his case against his former employer Nichia over recognition of his work towards the development of blue-emitting GaN lasers, and was awarded ¥20 billion by the Tokyo District Court (this figure was later downgraded by the Tokyo High Court to $¥ 840$ million). At around the same time, a former researcher from Hitachi was awarded $¥ 163$ million for the transfer of patent rights for his work on optical-disk development.

Nadya Anscombe 